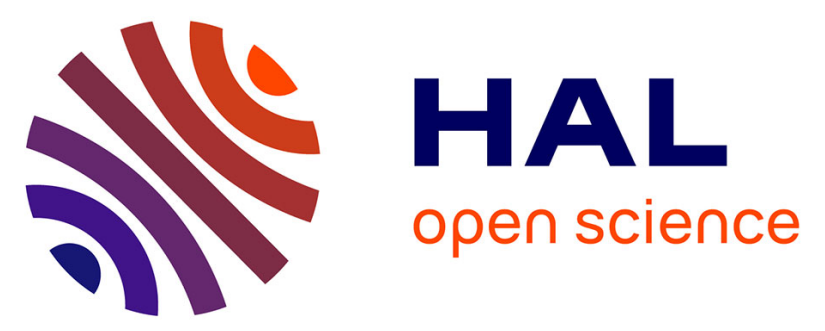

\title{
Installation of a thermal energy storage site in an abandoned mine in Picardy (France). Part 1: Selection criteria and equipment of the experimental site
}

Philippe Gombert, Gueye Abdoulaye, Haikel Ben Hamed, Hassen Beji, Farid Laouafa

\section{- To cite this version:}

Philippe Gombert, Gueye Abdoulaye, Haikel Ben Hamed, Hassen Beji, Farid Laouafa. Installation of a thermal energy storage site in an abandoned mine in Picardy (France). Part 1: Selection criteria and equipment of the experimental site. Environmental Earth Sciences, 2019, 78, pp.art. 174. $10.1007 / \mathrm{s} 12665-019-8128-0$. ineris-03319052

HAL Id: ineris-03319052

https://hal-ineris.archives-ouvertes.fr/ineris-03319052

Submitted on 11 Aug 2021

HAL is a multi-disciplinary open access archive for the deposit and dissemination of scientific research documents, whether they are published or not. The documents may come from teaching and research institutions in France or abroad, or from public or private research centers.
L'archive ouverte pluridisciplinaire HAL, est destinée au dépôt et à la diffusion de documents scientifiques de niveau recherche, publiés ou non, émanant des établissements d'enseignement et de recherche français ou étrangers, des laboratoires publics ou privés. 
Installation of a Thermal Energy Storage Site in an Abandoned Mine in Picardy (France). Part 1: Selection Criteria and Equipment of the Experimental Site.

Gombert Philippe ${ }^{1 *}$, Gueye Abdoulaye², Ben Hamed Haïkel², Beji Hassen², Laouafa Farid ${ }^{1}$

${ }^{1}$ INERIS, Parc Technologique Alata, 60550 Verneuil-en-Halatte, France

${ }^{2}$ Laboratoire des Technologies Innovantes, Université de Picardie Jules Verne d'Amiens, Avenue des Facultés le Bailly, 80025 Amiens Cedex, France

* philippe.gombert@ineris.fr

\title{
Acknowledgements
}

The authors thank the Picardy region for the grant awarded to the Demosthene project.

\begin{abstract}
As part of the new French law on energy transition, the Demosthene research project is studying the possibility of reusing old abandoned mines to store thermal energy in the Picardy region. The aim is to store the heat required for a small collective unit, which corresponds to a volume of water of 2,000 to $8,000 \mathrm{~m}^{3}$, depending on the temperature (from $15^{\circ} \mathrm{C}$ to $70^{\circ} \mathrm{C}$ ). An inventory shows around 3,700 theoretically available sites in this region. These are mostly shallow dry mines, or mines that are partially flooded with around $1 \mathrm{~m}$ of water depth. Based on this water depth and an extraction ratio of $75 \%$, the required mine area is approximately $10,000 \mathrm{~m}^{2}$. From the forty sites that have a sufficient surface area, only one is naturally flooded, although statistically many others will exist that are currently not known. In order for this experimental site to be reproducible, the decision was made to select dry mines but with a sufficient area to achieve an artificial flooding device. Theoretically, this represents more than a thousand sites in Picardy. The most interesting one is the old limestone mine of Saint-Maximin, where a sealed basin can be built. Before installing an experimental underground thermal energy storage basin in this site, the thermomechanical and hydrothermal behavior was modeled. The aim was to optimize the position of the various sensors that will be used to monitor the basin, and to predict the future deformations induced on the walls by the thermal variations. A $100 \mathrm{~m}^{3}$ basin, sealed with a liner, was built and fitted with eighteen sensors to measure temperature, humidity and strain. These sensors allow the stored water, the rock walls and the surrounding atmosphere to be monitored. This device must now operate for six months, i.e. a complete heating-cooling cycle, and its results will be analyzed.
\end{abstract}

Keywords: underground storage, thermal energy storage, mine, groundwater, inventory, basin, France

\section{Introduction}

The Energy Transition for Green Growth Law, passed in France on August 17, 2015, will accelerate the development of renewable energy sources (INERIS, 2016). The intermittent nature of some of these energy sources requires storing unconsumed energy to meet subsequent demand. This is particularly the case with thermal energy, which represents $44 \%$ of the total energy consumption in France (Bourbiaux, 2011). Underground storage is one way to solve such a problem but digging vast voids is very expensive compared to the price of energy, in particular thermal energy. One way to reduce the storage cost is to reuse old underground voids as abandoned mines.

The principle of underground thermal energy storage therefore consists in using the insulating properties of the subsoil to store heat or cold therein. In the seasonal storage concept, this thermal energy is recovered after a period of several months for heating or air conditioning purposes. It is a free thermal energy that can have two sources: (i) the conversion of excess electricity produced by certain renewable energy devices (Kabuth et al., 2016), or (ii) the waste heat due to the "unavoidable" energy released by some industrial processes (drying, cooling, waste incineration, liquid effluents discharges, etc.), agricultural processes (biomass maceration, greenhouse cooling, etc.) or household processes (heat pump discharges). 
Several hundred underground thermal energy storage devices exist in many countries for several decades (Sanner and Bartels 2009), primarily in Poland (Chwieduk 1997), Sweden (Axelsson et al. 1985; Brunström et al. 1985; Martna 1983), Belgium (Desmedt et al. 2006), Norway (Midttomme et al. 2008; Nielsen 2003), Germany (Seibt and Kabus 2006; Wille and Lottner 2006), Finland (Sipilä 1990), Denmark (Dannemand et al. 2013), Turkey (Paksoy et al. 2000), as well as in the Netherlands, Canada, the United States, etc. They essentially concern aquifer storages, with less than twenty storage sites that are located in cavities (Table 1). These are artificial caverns, full of water, and designed with a low diameter-height ratio (1 to 5) in order to reduce heat losses.

Table 1. Characteristics of main thermal energy storage projects in the world

\begin{tabular}{|l|c|c|c|c|c|c|c|}
\hline $\begin{array}{l}\text { Location } \\
\text { Country) }\end{array}$ & $\begin{array}{l}\text { Type of } \\
\text { storage }\end{array}$ & Shape of storage & $\begin{array}{c}\text { Depth } \\
(\mathrm{m})\end{array}$ & $\begin{array}{c}\text { Height } \\
\mathrm{H}(\mathrm{m})\end{array}$ & $\begin{array}{c}\text { Volume } \\
\left(\mathrm{m}^{3}\right)\end{array}$ & $\begin{array}{c}\text { Equivalent } \\
\text { diameter D }(\mathrm{m})\end{array}$ & D/H ratio \\
\hline Avesta (S) & Cavern & Tunnel & 25 & 30 & 15000 & 32 & 1.07 \\
\hline Lyckebo (S) & Cavern & Ring & $?$ & 30 & 104000 & 66 & 2.22 \\
\hline Oulu 2 (FL) & Cavern & Tunnel & 40 & 22 & 190000 & 105 & 4.77 \\
\hline Marstal (D) & Pit & Truncated prism & 0 & 16 & 75000 & 42 & 2.65 \\
\hline Vojens (D) & Pit & Truncated prism & 0 & 14 & 200000 & 135 & 9.64 \\
\hline Uppsala (S) & Tank & Cylinder & $?$ & 21 & 30000 & 42 & 2.00 \\
\hline Laxou (F) & Tank & Cylinder & 2 & 9 & 600 & 9 & 1.10 \\
\hline Poitiers (F) & Tank & Cylinder & 0 & 6 & 1000 & 15 & 2.43 \\
\hline St-Maximin (F) & Mine & Parallelepiped & 10 & 1,2 & 120 & 12 & 10.00 \\
\hline
\end{tabular}

The Demosthene ${ }^{1}$ research project is one of the few - if not the only one - in Europe to explore the possibilities of partially flooded abandoned mines, i.e. cavities with a high diameter-height ratio (>10) due to way they used to operate. It is funded by the Picardy region, located in the north of France, for the 2015-2018 period. Its goal is to achieve seasonal storage of thermal energy on an experimental site, representative of the abandoned mines in the Picardy territory. Apart from the unknown thermal energy recovery rate, mainly due to the geometry of the voids network, the main risk of such a technology is the impact of high temperature and humidity fluctuations on old underground structures that have not been built for this purpose. The Demosthene experimental site has been was built and equipped in this way, including a risk analysis aspect.

\section{State of the art of Underground Thermal Energy Storage}

\subsection{Introduction to the Different Types of Underground Thermal Energy Storage}

Underground thermal energy storage is divided into two major families based on the reservoir's characteristics-of:

- a closed system, where the thermal capacity of the rocks is used to store thermal energy; a heat transfer fluid is then used to recover that energy in the subsoil and transport it toward the surface heat exchangers (Midttomme et al. 2008); the system may be subdivided into vertical (boreholes) or horizontal (buried pipelines) types;

- $\quad$ an open system, where the thermal capacity of the groundwater is used, which is pumped, then re-injected underground; this system may also be subdivided into two types: (i) Aquifer Thermal Energy Storage (ATES) and (ii) Cave Thermal Energy Storage (CTES), the latter involving large hollowed-out caverns or pits, buried tanks, or mines.

\subsection{Underground Thermal Energy Storage in Caverns (Hard Rock context)}

In order to store large amounts of oil in Scandinavia (Figure 1), many underground caverns were hollowed out in the past (Martna 1983; IEA 1983; Axelsson et al. 1985; Brunström et al. 1985; Sipilä 1990; Nielsen 2003;

\footnotetext{
${ }^{1}$ Demonstrateur de Stockage d'énergie Thermique en carrière souterraine partiellement Ennoyée (Thermal energy storage demonstrator in partially flooded abandoned old mines).
} 
Midttomme et al. 2008; Fogelholm et al. 2008; Hellström 2012). This involves deep storage in hard rock allowing the creation of large voids (from 15,000 to $200,000 \mathrm{~m}^{3}$ ). Since the abandonment of fossil fuels in favor of renewable energies, most of these caverns have been reconverted into thermal energy storage reservoirs, particularly for heating neighboring towns (Gedung and Margen 1988). Water may be stored therein between 95 and $115^{\circ} \mathrm{C}$, which corresponds to a thermal capacity that can reach $10 \mathrm{GWh}$.

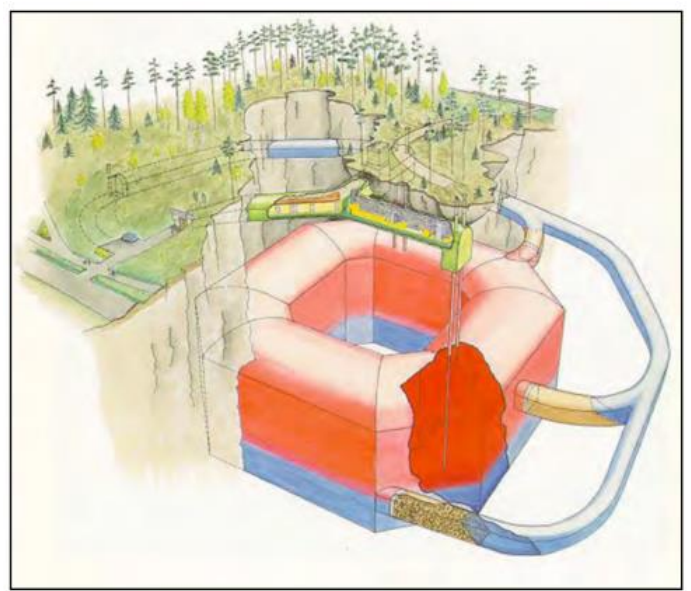

Figure 1. Scheme of the underground thermal energy storage cavern in Lyckebo, Sweden (Hellström, 2012)

The storage in abandoned mines is an alternative of the foregoing type. It corresponds to the reuse of pre-existing voids, designed for the extraction of materials and not for a fluid storage. The temperatures are generally more modest $\left(20\right.$ to $45^{\circ} \mathrm{C}$ ), but the volumes are much larger (several millions to tens of millions of $\mathrm{m}^{3}$ ). Several projects exist at this time: MineWater 2.0 in a Dutch coal mine (Verhoeven et al. 2014), Ely in a North-American iron mine (Allen et al. 1984; Walton and McSwiggen 1982), Sèvres in a French limestone mine (Arnould et al. 1983) and Mons in a Belgian chalk mine (Montjoie 1981).

\subsection{Underground Thermal Energy Storage in Pits or Tanks (Soft Rock context)}

This thermal energy storage type exists primarily in Denmark (Dannemand et al. 2013). It involves pits or ponds dug out from the surface, and covered so as to be isolated from the atmosphere (Photo 1). With a maximum depth of around $20 \mathrm{~m}$, these pits attain volumes of 75,000 to $200,000 \mathrm{~m}^{3}$. Water can be stored between 80 and $95^{\circ} \mathrm{C}$. Buried or semi-buried tanks, made from steel or molded concrete, also exist. Their volumes are generally smaller (several hundreds to thousands of $\mathrm{m}^{3}$ ), but they can attain $30,000 \mathrm{~m}^{3}$, as in Uppsala (Sweden) or Flensberg (Germany).

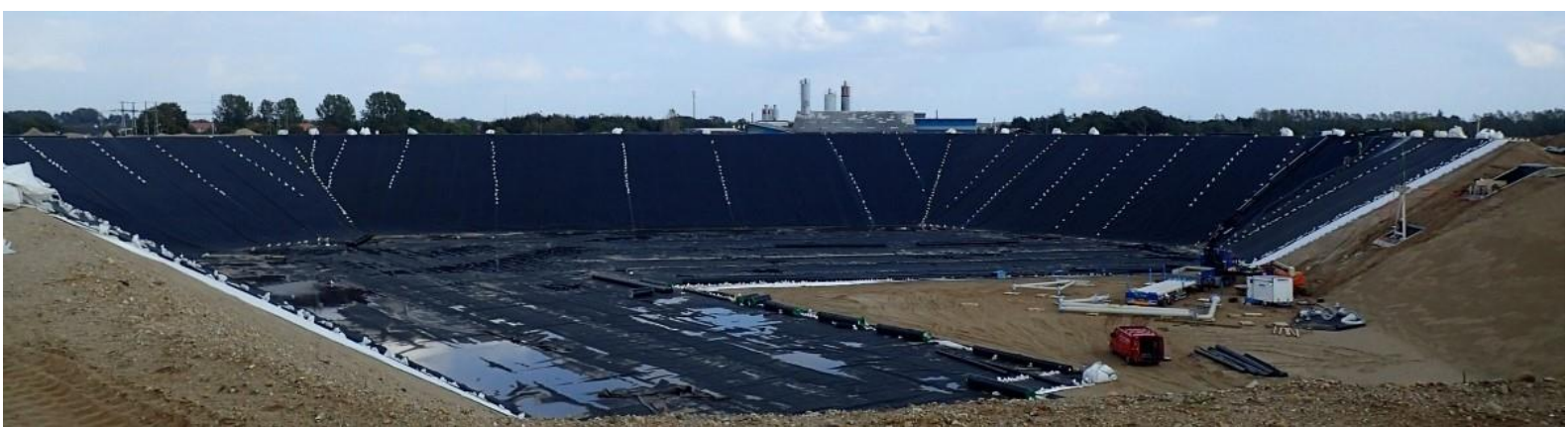

Photo 1. Excavation of the underground thermal energy storage pit in Vojens, Denmark (http://stateofgreen.com/en/profiles/ramboll/solutions/world-largest-thermal-pit-storage-in-vojens)

\section{Inventory of the Picardy Mines}

\subsection{General Information}

The subsoil of metropolitan France has approximately 500,000 excavated cavities that can be subdivided into natural caves (karsts) and artificial caves (mines, caves, military works, tunnels, etc.). There are approximately 300,000 mines, around 6,000 of them for extracting strategic materials (metals, salt, etc.) and all the others for extracting common materials (limestone, chalk, clay, gypsum, etc.). 
The mines for relative to non-strategic materials are more particularly of interest because they are generally shallow $(10$ to $30 \mathrm{~m}$ ), spread out over the national territory, and most often abandoned. It is not known precisely where most of them are not known located because they have been excavated and then abandoned for centuries.

\subsection{Establishment of the Inventory of the Picardy Mines}

A roughly estimate of the number of mines in Picardy would stand at approximately 30,000. The "National databank of abandoned underground cavities in metropolitan France, excluding deposits" counts only 7,345 underground cavities, the nature of which is only determined in $49 \%$ of cases: amongst these, $49 \%$ are true mines, or a total of 1,763 (see http://www.georisques.gouv.fr/).

The Geological Survey of Picardy (BRGM), the Ground and Underground Risks Department of Ineris, and the Amiens and Laon Departments of Mines, were also contacted to complete this information. They provided 25 mines that are not present in the Géorisques databank.

A total of 1,788 mines were located and determined (Figure 2a). However, approximately the same amount is located in the databank, but their exact nature has not been determined. This allows an overall estimate of between 1,800 and 3,600 known mines in Picardy.

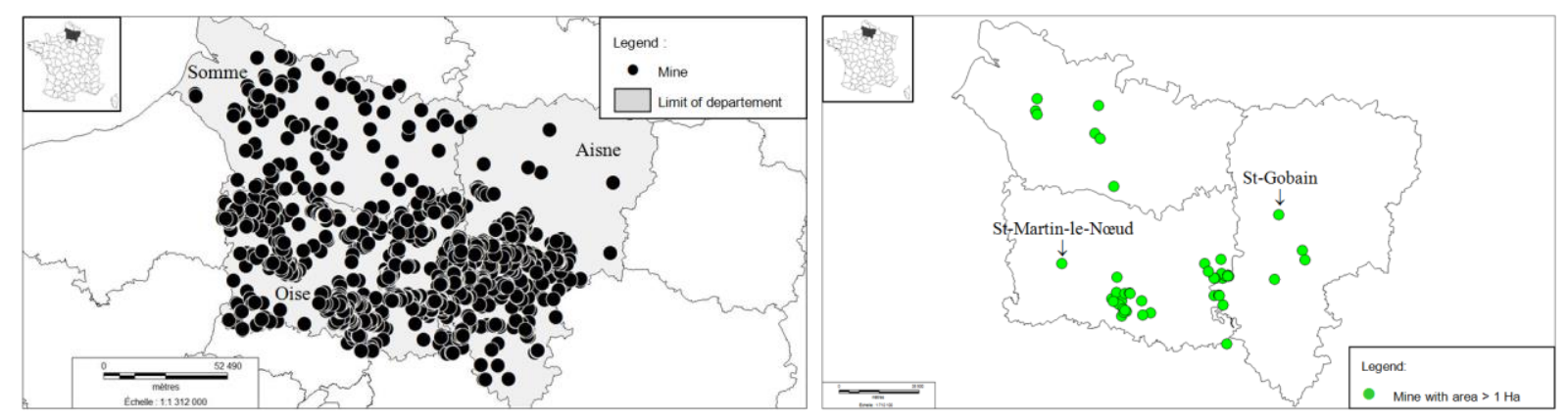

Figure 2. (a): Localization of the mines in the 3 Picardy departments and (b): Localization of mines with a surface area larger than or equal to $1 \mathrm{Ha}$.

\section{Selection of an Experimental Site}

\subsection{Description of the Experiment}

The future CTES will be designed for small collective units, such as gymnasiums, schools, shopping centers or small residential or office buildings. The amount of thermal energy to be stored is determined by the annual energy consumption of such buildings, taking into account 3 floors and a footprint of 1,000 $\mathrm{m}^{2}$. According to the data from the 2012 French thermal regulation (DGALN 2011), such a building has an energy need of 77 MWh of primary energy ${ }^{2}$ for winter heating under Picardy's climate. Using a water/air heat pump with performance coefficient modified by operating auxiliaries (COE) of 7, the necessary energy storage is $66 \mathrm{MWh}$. At the temperature of $15^{\circ} \mathrm{C}$, this corresponds to a water volume of $3,800 \mathrm{~m}^{3}$, and only $800 \mathrm{~m}^{3}$ at the temperature of $70^{\circ} \mathrm{C}$. Since it is necessary to have one storage for hot water and another for cold water, the volume of water ultimately necessary is doubled, i.e., between 1,600 and 7,600 $\mathrm{m}^{3}$.

The experimental storage will be used to design such a future CTES, taking into account the water losses, thermal transfer through the rock (walls, floor) and the overlying air layer. The decision was made to study heat storage in a natural or artificial underground hot basin at the scale 1/10, i.e. with a volume between 80 and $380 \mathrm{~m}^{3}$ depending on the targeted temperature. The planning of the experiment will be as follows: simulation of "summer" heating of water from April to September, then simulation of "winter" use of stored heat from October to March.

\subsection{Geological and hydrogeological context of Picardy}

Located between Paris and Belgium, Picardy includes three departments that extend over a cumulative area of $19,400 \mathrm{~km}^{2}$ : Aisne, Oise and Somme. The northern part of this region is made up of vast plateaus divided by several dry valleys and a few humid valleys such as that of the Somme and its tributaries. It corresponds to subtabular deposits of Upper Cretaceous chalk, about $200 \mathrm{~m}$ thick, frequently topped by Quaternary loess (Figure 3). In the southern part, the chalk is covered by the Tertiary formations of the Paris basin forming hills: nevertheless,

\footnotetext{
2 i.e. including the energy needed for electricity production and transport (in France, 1 Wh billed by the electricity supplier corresponds to $2.58 \mathrm{Wh}$ of primary energy or $\mathrm{Wh}_{\mathrm{pe}}$ ).
} 
the topography remains modest, with a culminating point of $230 \mathrm{~m}$ a.s.l. Here, the main rivers are the Oise, flowing at around $30 \mathrm{~m}$ a.s.l, and its principal tributary, the Aisne.

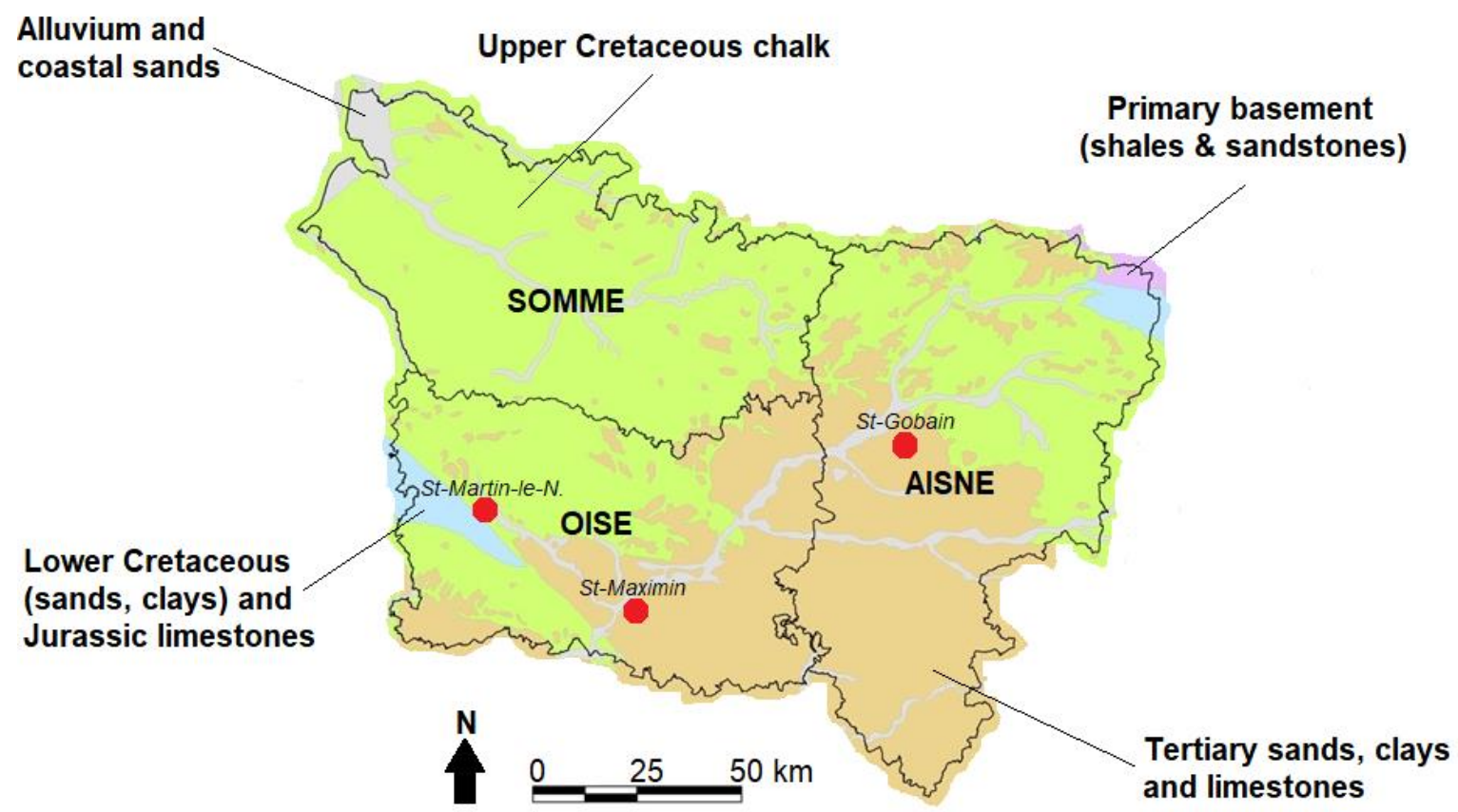

Figure 3. Geological sketch of Picardy showing the 3 studied sites (red circles)

From a hydrogeological point of view, the chalk contains a vast aquifer located about 20 to $50 \mathrm{~m}$ deep below the plateaus and connected to the rivers in the valleys, by way of alluvium aquifers. The Eocene limestones and sands, included in Tertiary deposits, generally have perched and localized aquifers.

Several thousand mines have been dug in the chalk and the limestone formations. The selection of the most interesting for the installation of an experimental site is based on three main parameters: (i) the surface area of underground voids, (ii) their accessibility from the surface, and (iii) their flooding conditions. Furthermore, it is necessary for the selected site to be representative of a significant number of other mines in the Picardy region, so that the experimental device can be reproduced on a broader scale.

\subsection{Minimum Cave Surface Area Criterion}

The surface area of the mine needed to produce the experimental site is based on the following three parameters:

- $\quad$ The quantity of thermal energy to be stored (see chapter 4.1);

- The depth of flooding water;

- The extraction ratio of the mine (the ratio of the exploited surface area to the whole surface area).

The water depth varies from about 1 to $4 \mathrm{~m}$ depending on the level of flooding. The minimal acceptable value was defined on the basis of a numerical simulation of the heat transfer in a fluid and solid medium (see Table 2 and chapter 5.2). The results show that the water brought to $70^{\circ} \mathrm{C}$ is, after six months, between $35^{\circ} \mathrm{C}$ and $52^{\circ} \mathrm{C}$, depending on the water depth. Although it is preferable to have the maximum water depth, it was considered that a minimum of $1 \mathrm{~m}$ would be acceptable, since it makes it possible to recover water at $35^{\circ} \mathrm{C}$ after six months of underground storage. This makes it possible to consider that the minimum surface area of basins necessary to store the volume of water previously calculated is between 1,900 and $7,600 \mathrm{~m}^{2}$, depending on the storage temperature. As the extraction ratio is generally between 60 and $80 \%$ in the French chalk or limestone mines (Tritsch 2007), with an average value of $75 \%$ in old mines, that gives a mine surface area of 2,500 to $10,100 \mathrm{~m}^{2}$.

Table 2. Simulation of the influence of the watering height of the mine on thermal loss of the stored water 
Calculation hypotheses: basin of $2500 \mathrm{~m}^{2}(50 \mathrm{~m}$ x $50 \mathrm{~m})$, topped by a layer of air of $2 \mathrm{~m}$ with water brought from $10^{\circ} \mathrm{C}$ to $70^{\circ} \mathrm{C}$

\begin{tabular}{|l|c|c|c|}
\hline Thickness of the water space & $4 \mathrm{~m}$ & $2 \mathrm{~m}$ & $1 \mathrm{~m}$ \\
\hline Temperature lost after 6 months & $\sim 18{ }^{\circ} \mathrm{C}$ & $\sim 29^{\circ} \mathrm{C}$ & $\sim 35^{\circ} \mathrm{C}$ \\
\hline Residual heat after 6 months & $\sim 52{ }^{\circ} \mathrm{C}$ & $\sim 41^{\circ} \mathrm{C}$ & $\sim 35^{\circ} \mathrm{C}$ \\
\hline
\end{tabular}

Based on these calculations, it was therefore considered a surface area of $10,000 \mathrm{~m}^{2}(1 \mathrm{Ha})$ for a mine to be used as an experimental thermal energy storage site. According to the previous database, 40 sites are known to meet this criterion in Picardy, i.e. $31 \%$ of the localized and known mines (Figure 2b). Conversely, more than a thousand of mines are supposed to meet this criterion but their location is not known precisely.

\subsection{Criterion Regarding Mine Flooding}

The following selection criterion relates to the flooding condition of the mines. Such information is only available for twenty-six of them, out of the forty previously identified as having a sufficient surface area. Nineteen mines are were declared "dry", while only seven show traces of water: six in the form of dampness or temporary and localized infiltrations, primarily during rainy periods, while a single one was declared as "partially flooded". This is the Larris Millet chalk mine, located at Saint-Martin-le-Nœud (Oise), the lowest galleries of which are under the water table level, forming around 20 permanent lakes (Photo 2a).

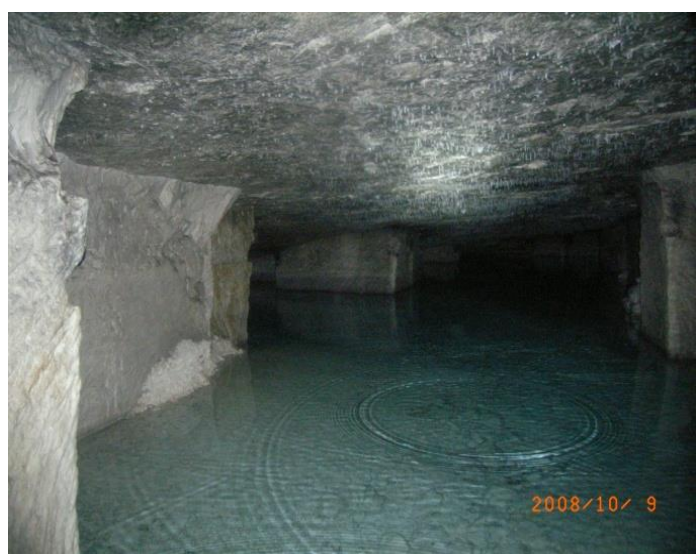

a) Natural lake of the Saint-Martin-le-Nœud

flooded chalk mine (INERIS)

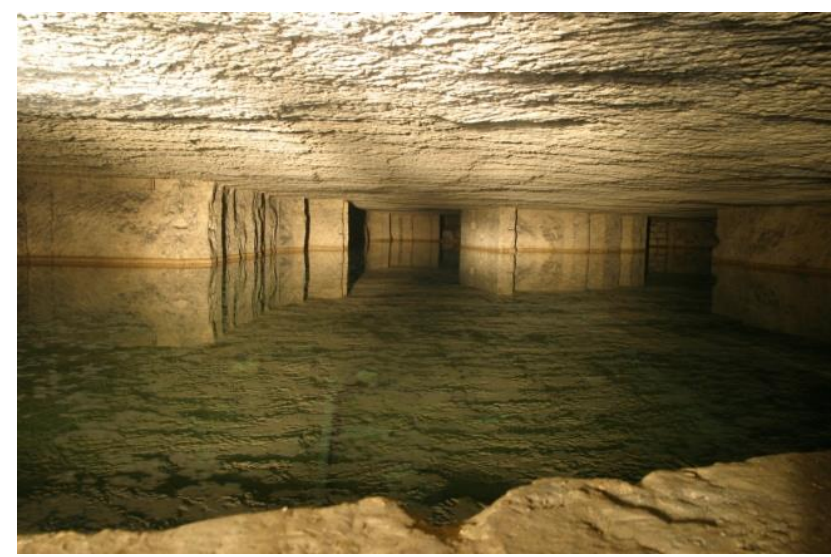

b) Artificial basin of the Saint-Gobain limestone mine (FX Déssirier \& APS)

Photo 2. Potential basins inside the St-Martin-le-Noeud and St-Gobain mines

The proportion of partially flooded mines is therefore approximately $4 \%$ amongst those with a surface area greater than or equal to $1 \mathrm{Ha}$. By applying this proportion statistically to the thousands of other mines that cannot be located, there should be around forty other partially flooded mines with a sufficient surface area. Ultimately, in Picardy, there must be more than forty mines able to serve as thermal energy storage sites, but only one of them is actually known.

\subsection{Other Possibilities of Experimental Site}

The only known flooded mine in Picardy is the chalk mine of Saint-Martin-le-Nœud, but building an experimental site there does not mean it can be reproduced on a regional scale, since the location of other potentially interesting mines is not known at this time. The possibility was examined of using the many dry mines with a minimum surface area of $1 \mathrm{Ha}$, through use of an artificial flooding device: digging out basins directly in the hard rock, or sealing galleries with a liner once they have been partially backfilled with porous materials. Two mines are particularly interesting for such an experiment. 
The first one is that of the "Manufacture Royale des Glaces de Miroirs" located in Saint-Gobain (Aisne) and exploited for the extraction of Lutetian limestone since the Middle Ages, using the chamber and pillar method. This mine extends over 40 ha and is $15 \mathrm{~m}$ deep, that is $45 \mathrm{~m}$ above the water table. Two main basins were artificially excavated into the limestone with a volume around $850 \mathrm{~m}^{3}$ to store the water necessary to manufacture large mirrors (Figure 4a and Photo 2b). Despite local water infiltrations, this is a dry mine supplied with surface water by an aqueduct. The basins are closed by several masonry walls. This site in fact poses two main problems for such an experiment: the significant volume of the basins will need a long heating time, and a total watertightness is not guaranteed for the long period of time (12 months) necessary for the experiment.

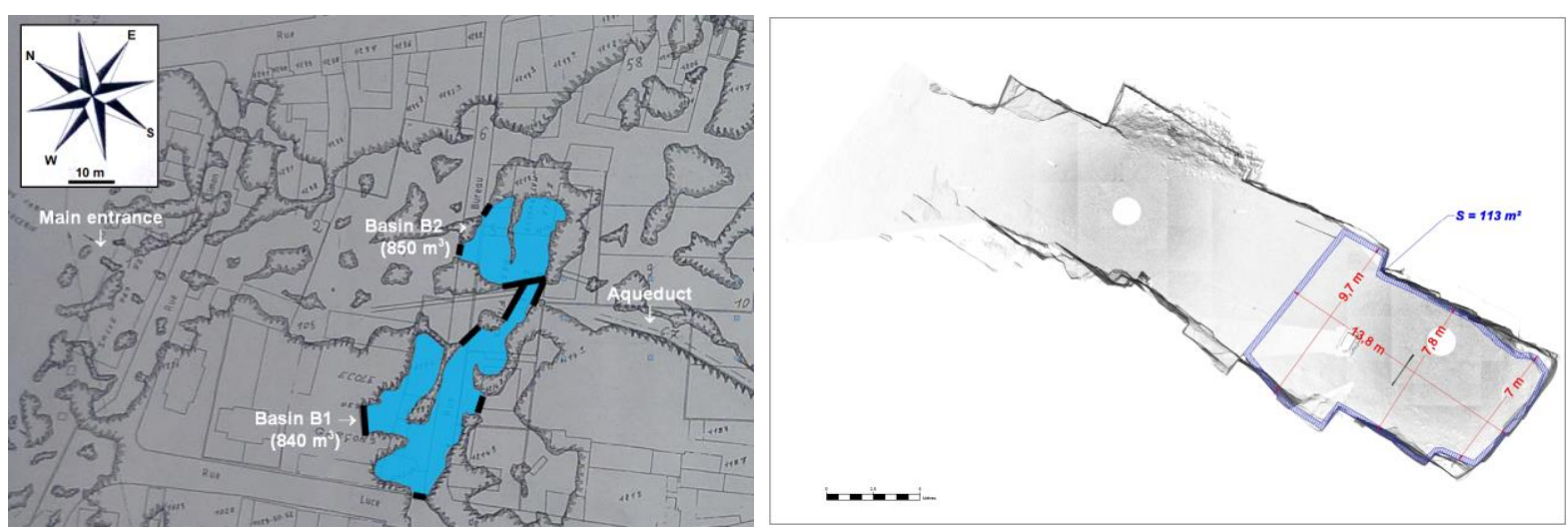

Figure 4. (a): Map of existing basins inside the St-Gobain mine (black lines are built dams) and (b): map of the basin in the experimental gallery inside the St-Maximin mine

The second one is the Parrain's mine located in Saint-Maximin (Oise). This is also an old limestone mine with an area of $6 \mathrm{Ha}$, located $10 \mathrm{~m}$ underground and $10 \mathrm{~m}$ above the water table. As its high galleries have been backfilled over with 1.50-2 m, it is not economically viable to excavate a basin and reach the hard rock. Moreover, a previous permeability test of the rock-wall has highlighted several leakages due to cracks. To avoid any losses by infiltration through the walls and the floor of this mine, a perfectly sealed basin must be envisaged here.

\subsection{Final Site Selection and Building}

The Saint-Maximin site was ultimately selected for the future experimental underground heat storage basin. A dam ( $8 \mathrm{~m}$ width, $1.50 \mathrm{~m}$ high) was built with the purpose of isolating the end of a gallery (14 $\mathrm{m}$ long) and a liner was installed to obtain a $120 \mathrm{~m}^{3}$ basin (Figure $4 \mathrm{~b}$ and Photo 3). Because of the presence of cracks at the ceiling, it was necessary to implement safety measures beforehand (support struts).

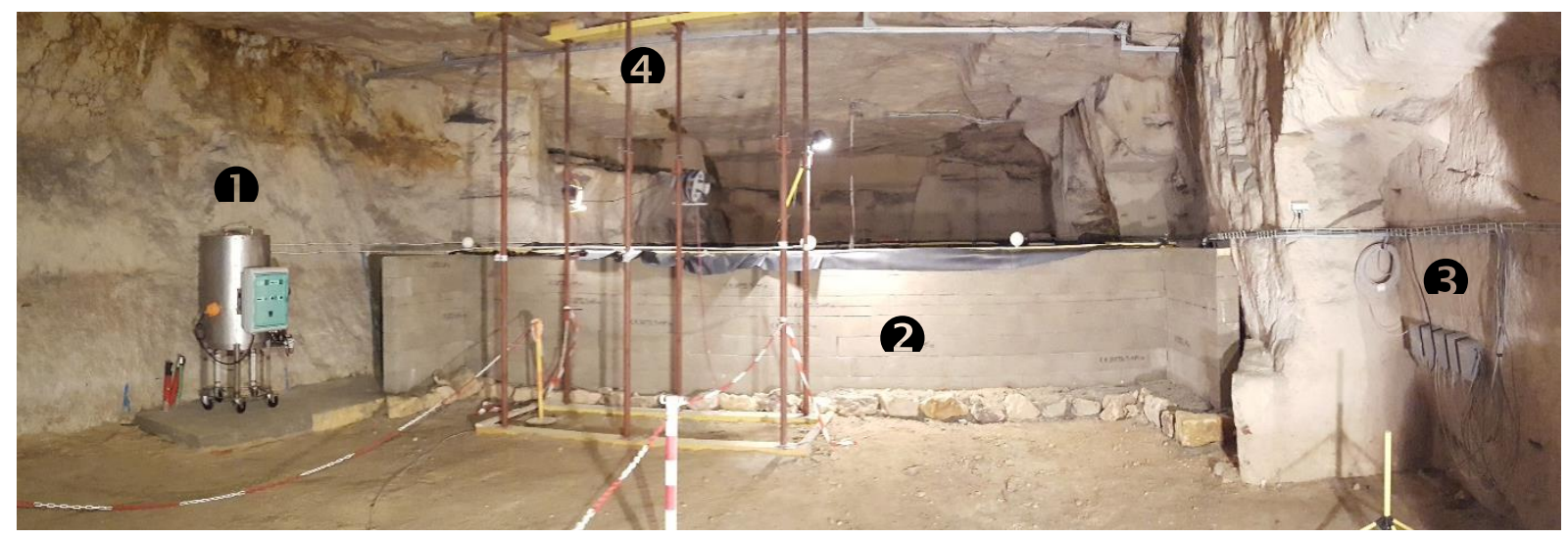

Photo 3. View of the experimental basin built inside the St-Maximin mine

(Legend: $\mathbf{0}$ = electric water heater, $\mathbf{2}=$ dam, $\mathbf{3}=$ data loggers, $\mathbf{4}=$ roof support $)$

The basin has then been filled with water initially at $10{ }^{\circ} \mathrm{C}$, that will gradually be heated to $80{ }^{\circ} \mathrm{C}$ over six months. At the surface, there might be a $180 \mathrm{~m}^{2}$ collective unit equipped with $120 \mathrm{~m}^{2}$ of thermal solar sensors. An electric

\footnotetext{
3 i.e. the "Royal Mirror Glass Works" that was founded in 1665 by Colbert, Louis XIV's Finance Minister.
} 
water heater, whose power is adjustable up to $6 \mathrm{~kW}$, simulates the summertime operation of such device in the Picardy climate. The quantity of thermal energy thus stored will be $6.2 \mathrm{MWh}$.

5. Design, Instrumentation and Operation of the Experimental Site

\subsection{Hydrothermal Modetling}

With regard to the basin's thermal operation, pre-modeling was performed using the COMSOL calculation code. Figure 5 represents the geometric model of the hot water storage basin, which includes a hot water injection well near the upstream surface of the basin and a cold water pumping well near its downstream base, at the foot of the dam.

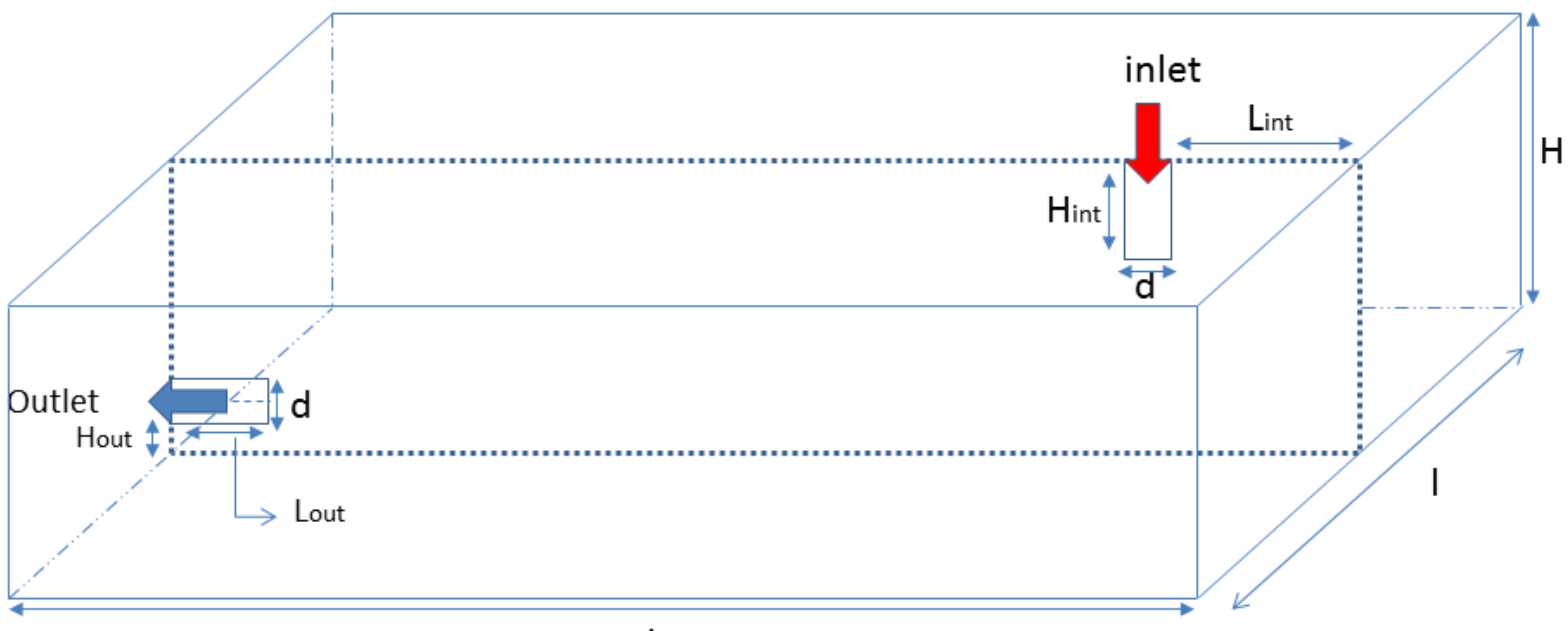

\section{L}

Figure 5. Scheme of the thermal storage basin geometry

The study was performed by making the following simplified hypotheses: Incompressible fluid, negligible viscous dissipation, constant thermodynamic properties with the exception of the variation in density with temperature and taking the effects of gravity into account. The Navier-Stokes and tridimensional energy equations were used to resolve this problem. Taking into account the Boussinesq approximation, the balance equations are as follows:

- Continuity equation: $\nabla \cdot \boldsymbol{V}=0$

- Momentum equation: $\quad \rho \frac{\partial \boldsymbol{V}}{\partial t}+(\rho \boldsymbol{V} \cdot \boldsymbol{V}) \boldsymbol{V}=-\nabla p+\nabla \tau-\rho \beta\left(T-T_{0}\right) \boldsymbol{g}$

- Energy conservation equation: $\rho C_{p} \frac{\partial T}{\partial t}+\rho C_{p} \boldsymbol{V} \cdot \nabla T=\nabla \cdot(k \nabla T)$

where $V$ is the fluid velocity field, $p$ is the fluid pressure, $\tau$ the shear stress, $g$ the acceleration of gravity, $\rho$ the fluid density, $\beta$ the volumetric expansion coefficient, $k$ the thermal diffusivity, and $C_{p}$ the specific heat capacity.

A variable flow condition (Table 3) was applied to the entry of the injection well, while a constant pressure condition was applied to the exit of the pumping well. Variable boundary conditions were applied to the model. The determination of the skin effect is based on a phase difference between the water and the rock temperature, depending on the heating frequency. In our computations, for a half-period (180 days), the thickness of the skin effect is find equal to $0.10 \mathrm{~m}$. The maximum temperature difference observed inside the skin is around $0.7^{\circ} \mathrm{C}$.

Table 3. Initial flow rate (L.min-1) condition during 6 months

\begin{tabular}{|l|l|l|l|l|l|l|}
\hline \multirow{2}{*}{$\begin{array}{l}\text { Months } \\
\text { Flow rate(1/min) }\end{array}$} & April & May & June & July & August & Sept \\
\cline { 2 - 7 } & 0.13 & 0.76 & 0.89 & 1.20 & 0.94 & 0.40 \\
\hline
\end{tabular}

A thermally insulating covering was placed at the water-air interface, limiting thermal exchanges. The velocity was zero at all walls. The numerical study was performed with a temperature of $80^{\circ} \mathrm{C}$ at injection for an initial basin water temperature of $10^{\circ} \mathrm{C}$. 
The equations for conservation of mass, momentum and energy with the conditions at their upper limits were discretized using the finite element method and solved on Comsol with the help of the Pardiso equation solver. Pardiso is a reference for the direct solving of linear matrix systems by LU decomposition. One opted for a regular triangular mesh shown in figure 6 formed of 111,166 domains with sides $d x=d y=d z=0.2 \mathrm{~m}$. The convergence of calculations was verified by a mesh refinement.

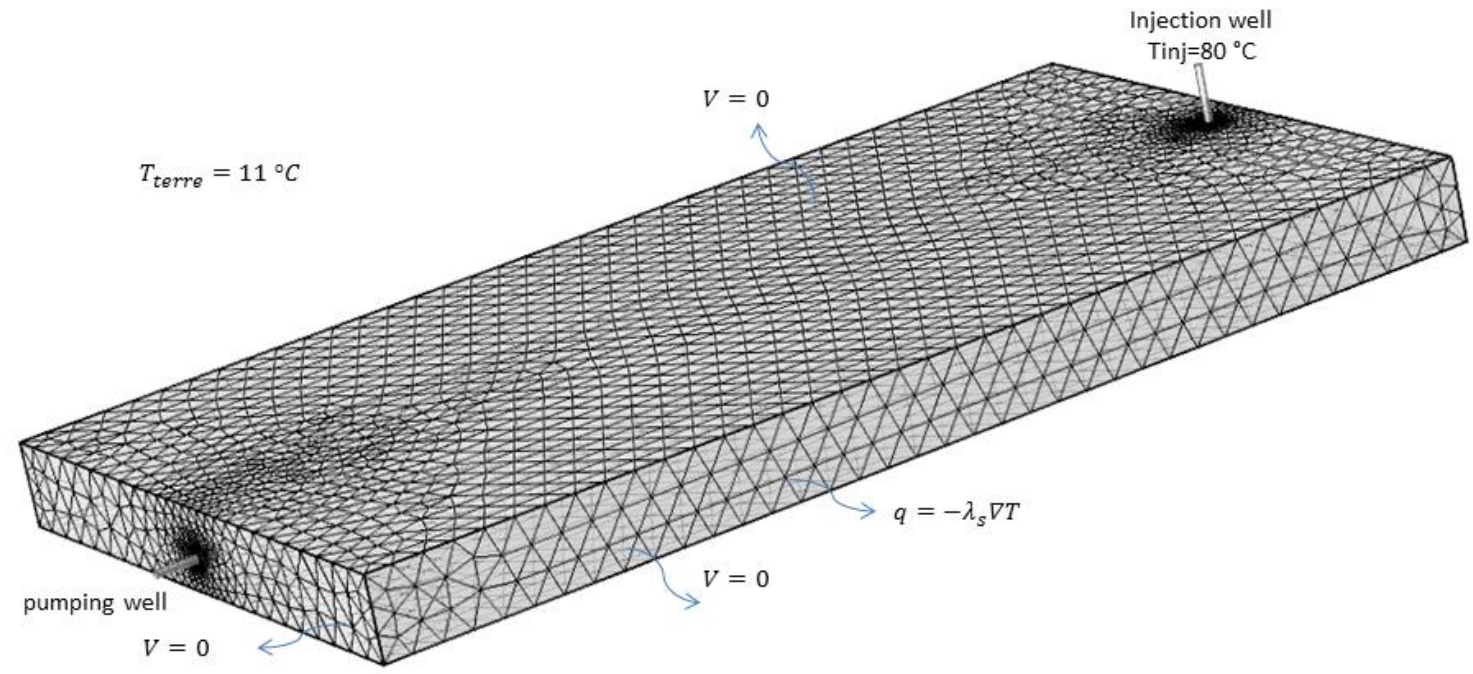

Figure 6. Regular triangular mesh of the model

Temperature stratification in the storage basin was influenced by various factors such as the basin's dimensions (length L, width w, height h) and the placing of water inlets and outlets. Consequently, the flow section illustrates the effect of the aspect ratio $\mathrm{A}=\mathrm{L} \cdot \mathrm{w}^{-1}$ as well as the placing of the water inlets and outlets, over the temperature distribution inside the reservoir at different times. Thus, Figure 7 presents the temperature curves for the loading process for an aspect ratio varying from 1.50 (basin under construction) to 2.50 (basin initially planned) with $\mathrm{t}=183$ days. In these case studies, water height and basin width were constant, and their respective values were $1 \mathrm{~m}$ and $8 \mathrm{~m}$, but with length varying from 11 to $20 \mathrm{~m}$ in order to provide the required proportions.

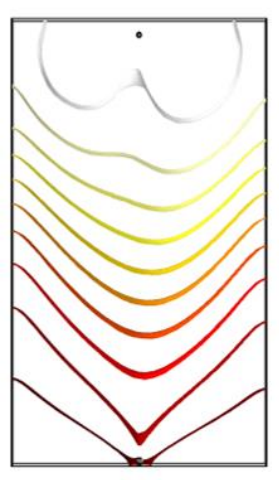

$A 1=1,50$

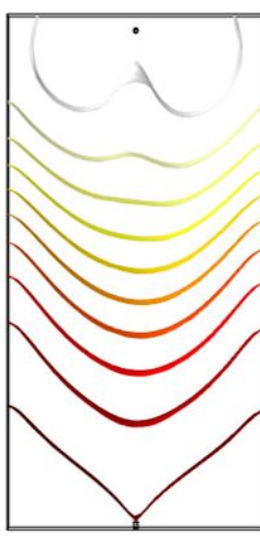

$A 2=1,75$

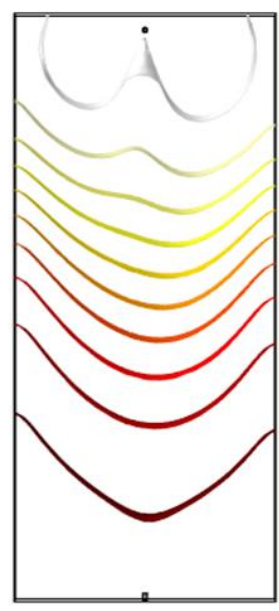

$A 3=2,00$

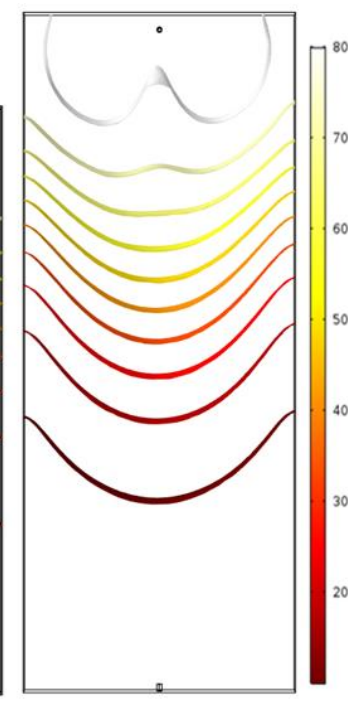

$A 4=2,25$

Figure 7. Role of the aspect ratio A

Shown here is the change in temperature distribution in a thermal load cycle after 100 days (Figure 8a) and 183 days (Figure $8 \mathrm{~b}$ ) after the initial load, for an aspect ratio of 1.50 for the projected basin. The temperature distribution in the basin shows a concentration of heat on the side of the injection zone for the entire duration of 
the heating cycle (183 days). To optimize the system's performance, the water temperature in the pumping well must change as little as possible during the heating period.

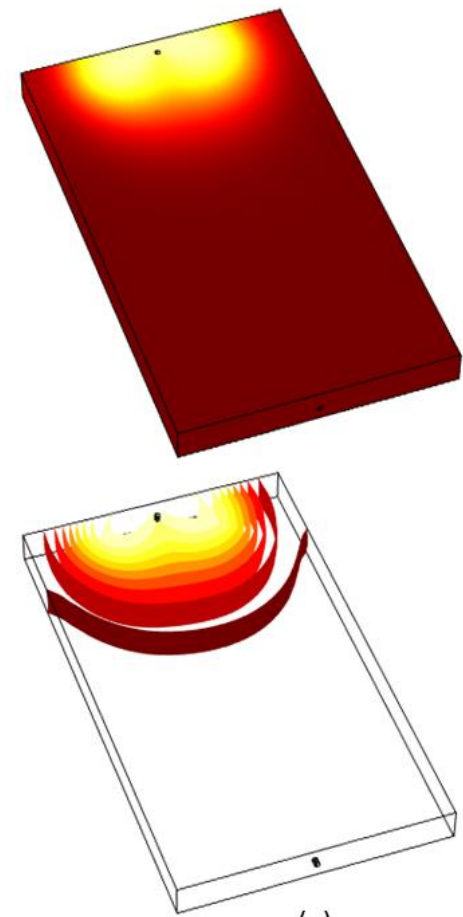

(a)

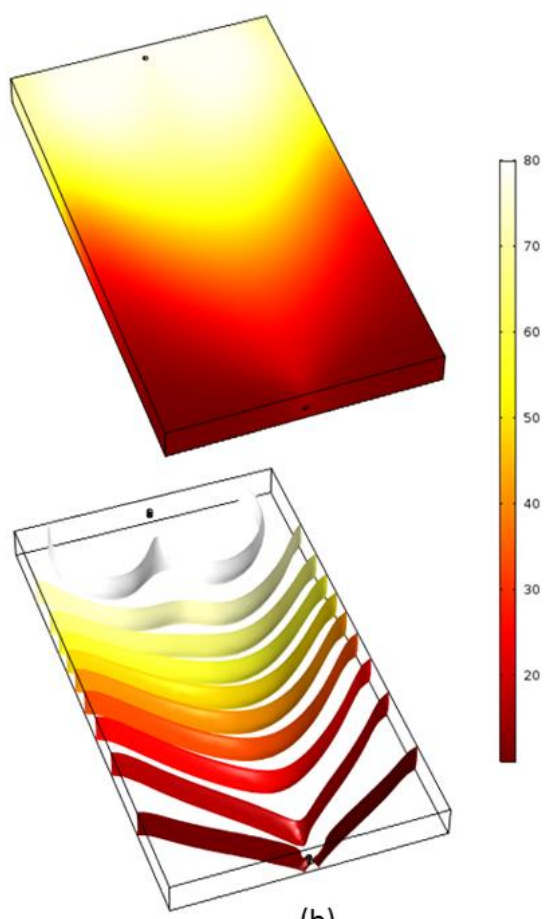

(b)

Figure 8. Temperature distribution and isothermal contours indicating the flow field at time 62 days (a) and 180 days (b) in A1 configuration

The numerical study performed shows a slight temperature increase in the pumping wells (Figure 9b) at the end of the heating cycle. The final average water temperature for the entire basin attained approximately $50^{\circ} \mathrm{C}$ (Figure 9a) in this configuration.

(a)

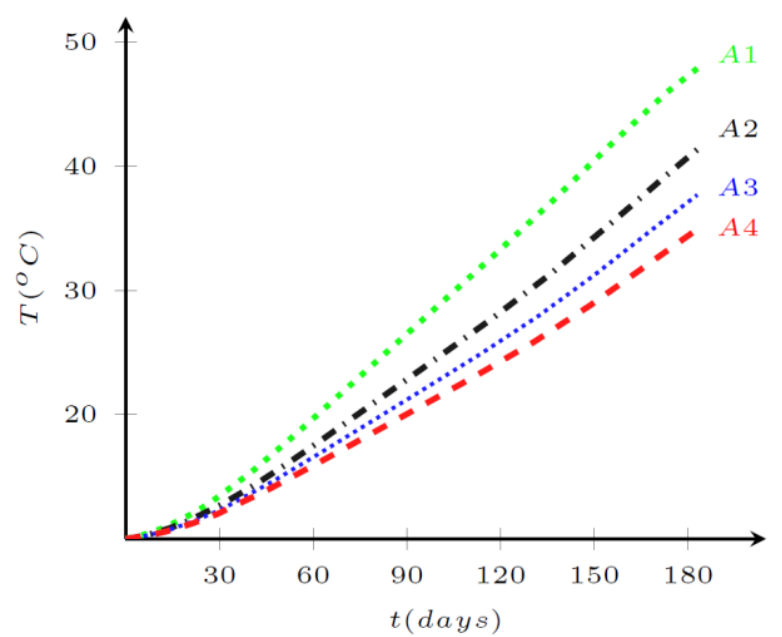

(b)

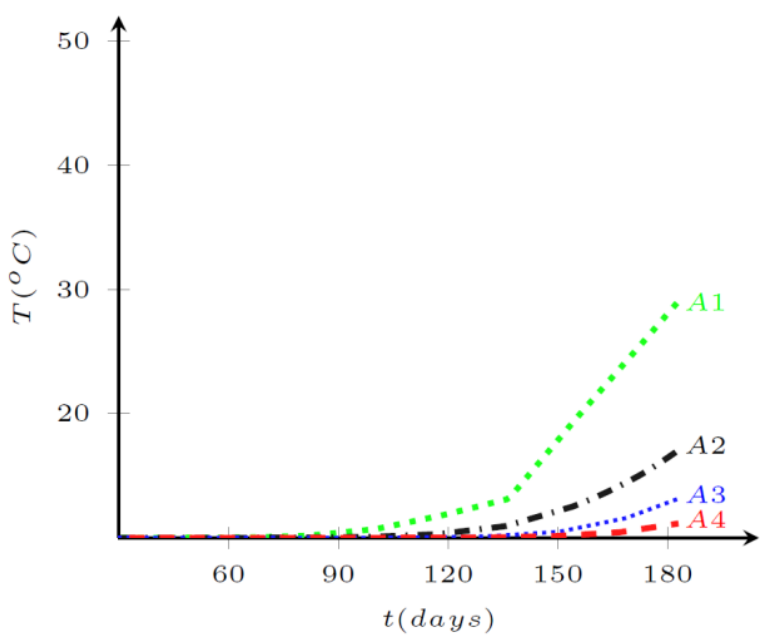

Figure 9. Average water temperature (a) and outlet temperature (b) for different aspect ratios A

\subsection{Thermo-Elastoplasticity Modelling}

The purpose of this section is to show the thermomechanical response induced by the temperature change, from a strictly thermo-elastoplasticity-related perspective. The thermal properties of rocks depend strongly on their 
mineralogical composition, porosity ( $\phi$ ), saturation, etc. (Fjaer et al. 1992). Somerton (1992) has shown that for different rock materials, thermal properties depend not only on the nature of their minerals but also on the temperature to which they were subject. In our experiment, the maximum temperature is low, therefore mechanical and thermal features can be considered as constant and temperature independent.

For the thermal expansion of matrix $\alpha$, a spherical thermal expansion was assumed, while in fact it is generally anisotropic or tensorial (Somerton 1992). Table 4 shows the values of thermal properties that were taken for eur numerical analyses. The values of these parameters correspond to average values for limestone.

Table 4. Mechanical and thermal properties used in the model

\begin{tabular}{|c|c|c|c|c|c|c|c|}
\hline \multirow[t]{2}{*}{$\begin{array}{l}\text { Type of } \\
\text { material }\end{array}$} & \multirow{2}{*}{$\begin{array}{c}\text { Young's } \\
\text { modulus } \\
(\mathrm{GPa})\end{array}$} & \multirow[t]{2}{*}{$\begin{array}{l}\text { Poisson's } \\
\text { ratio }\end{array}$} & \multirow{2}{*}{$\begin{array}{c}\text { Thermal } \\
\text { conductivity } \\
\left(\mathrm{W} \cdot \mathrm{m}^{-1} \cdot \mathrm{K}^{-1}\right)\end{array}$} & \multirow{2}{*}{$\begin{array}{c}\text { Heat } \\
\text { capacity } \\
\left(\mathrm{J} \cdot \mathrm{kg}^{-1} \cdot \mathrm{K}^{-1}\right)\end{array}$} & \multirow{2}{*}{$\begin{array}{l}\text { Density } \\
\left(\mathrm{kg} \cdot \mathrm{m}^{-3}\right)\end{array}$} & \multicolumn{2}{|c|}{$\begin{array}{c}\text { Expansion coefficient } \\
\left({ }^{\circ} \mathrm{C}^{-1}\right)\end{array}$} \\
\hline & & & & & & (min) & $(\max )$ \\
\hline Rock & 15 & 0.3 & 2 & 800 & 2200 & $10-6$ & $510-6$ \\
\hline Backfill & 1 & 0.3 & 0.5 & 890 & 2200 & $10-6$ & $510-6$ \\
\hline
\end{tabular}

In our finite element modeling, two values for thermal expansion were considered: $\alpha_{1}=10^{-6}{ }^{\circ} \mathrm{C}^{-1}, \alpha_{2}=5 \times 10^{-6}{ }^{\circ} \mathrm{C}^{-}$ ${ }^{1}$. These two values are consistent with the limestone thermal expansion coefficient.

Some thermomechanical concepts are listed very briefly below. For more details, the reader may refer to the many textbooks and articles on this subject (Gurtin et al. 2009; Holzapfel 2000; Barron et al. 2012).

The equation for heat transfer by conduction (neglecting transfer by convection in solid matrix) is described by the following equation: $\frac{\partial T(\boldsymbol{x}, t)}{\partial t}=\nabla . k \nabla T(\boldsymbol{x}, t)$ with $k=\frac{\lambda}{\rho c_{p}}$

where $k$ is the thermal diffusivity, $T$ the temperature, $x$ the space coordinate of the point in the material and $t$ the time. $(\nabla)$ and $(\nabla$.$) represent the gradient and divergence operators respectively. In the case of a homogeneous$ material, and assuming that the diffusivity properties do not depend on the temperature, it has the following relationship: $\frac{\partial T(\boldsymbol{x}, t)}{\partial t}=k \Delta T(\boldsymbol{x}, t)$

In the simulations, this expression was adopted for the thermal transfer by conduction, and weak thermomechanical coupling was assumed in the sense that the mechanical response does not affect the thermal properties of the rock, but the temperature fields contribute to the mechanical response by way of the thermal expansion coefficient.

The modeling results presented below were obtained under the small deformation hypothesis (small strains and small displacements) and within the classical theory of elastoplasticity. Thus, the total strain $(\varepsilon)$ is the additive sum of the elastic strain $\varepsilon^{\mathrm{e}}$, plastic strain $\varepsilon^{\mathrm{p}}$ and temperature-induced strain $\varepsilon^{\text {th }}$. The thermal strain obeys the following relationship: $\varepsilon^{\text {th }}(\boldsymbol{x}, t)=\alpha(T(\boldsymbol{x}, t)-T 0(\boldsymbol{x}))$

The thermal expansion coefficient, $\alpha$ is assumed isotropic, $(T(x, t)-T 0(x))$ represents at a material point the variation in temperature from the reference temperature $T \mathrm{O}(\boldsymbol{x})$.

The following assumptions were adopted for all calculations performed within a non-linear thermo-mechanical finite elements framework:

- the rocks media is assumed to be continuous (without fault or any discontinuities),

- the analyses are performed within the classical elastoplastic formalism,

- the Mohr-Coulomb model is used to describe the elastic limit of the rocks,

- small strains and displacement are assumed,

- inertial terms are neglected (quasi-static problems),

- the mathematical coupling between mechanics and heat is a weak coupling (unidirectional), 
- the problems are purely thermomechanical (thermoelastic, thermo-elastoplastic). In this first approach, the pore water pressure is deliberately excluded due to the temperature and its rate of change, which are not high enough to generate high pore water pressure. Geomechanical properties of rocks depend on their sites and values such as strength, for example, depend on the scale effect and genesis, among other things.

The reader can refer to Fjaer et al. (1992) for mechanical and thermal properties of some rocks. Among all the mechanical and thermal properties that were identified, representative average values were extracted (Table 4). Regarding the overburden, its Young's modulus is assumed to be small ( $1 \mathrm{GPa}$ ) in order to consider the overburden as a dead load, its Poisson's ratio is equal to 0.3 , its cohesion is equal to $5 \mathrm{MPa}$ and the friction angle is equal to $35^{\circ}$. Several calculations were performed by varying all these parameters in ranges of realistic values. They do not change our conclusion resulting from our modeling since the thermal stresses are not significant to produce plasticity in rock matrix.

Figure 10 shows the 3D model, boundary conditions and finite element mesh. Due to symmetry (mechanical and geometrical), only half the model is considered.
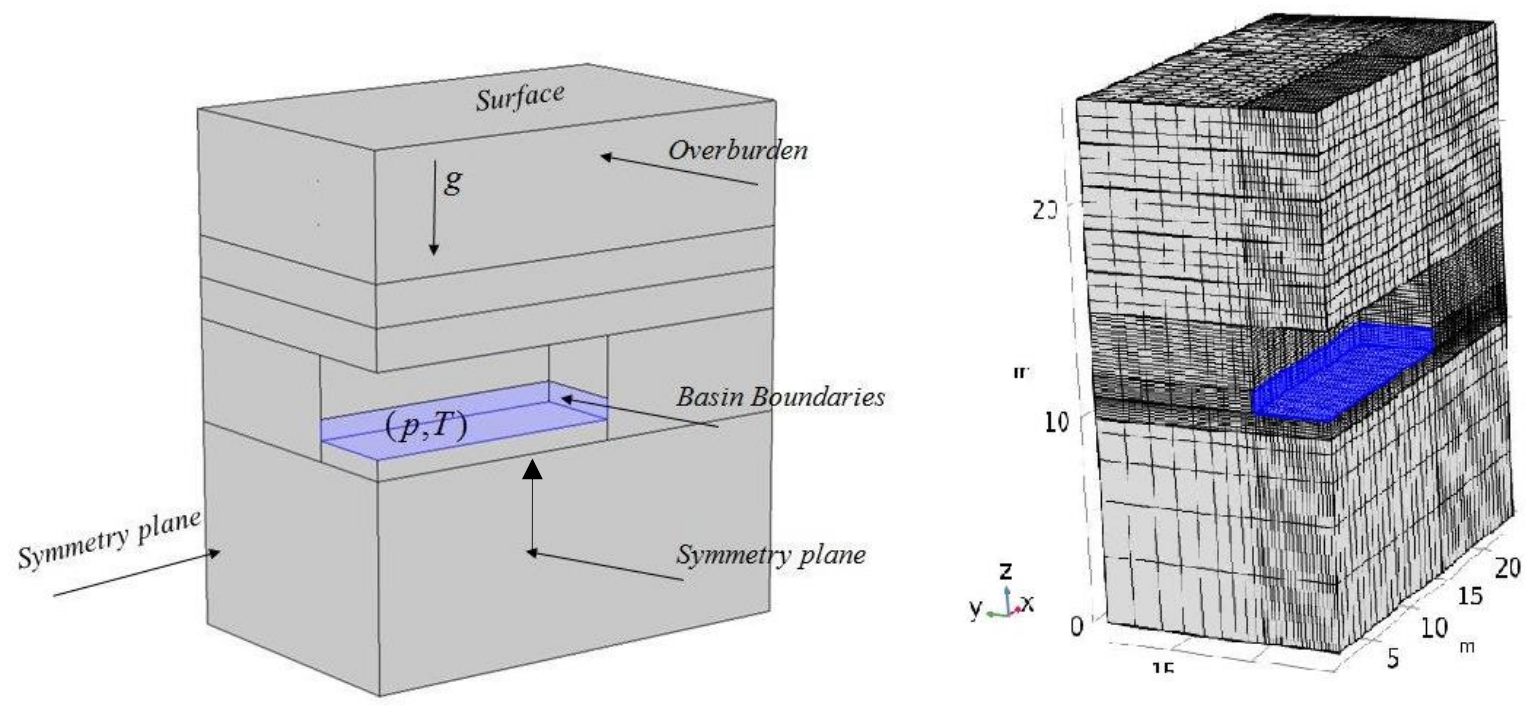

Figure 10. Geometrical model (left) and finite element mesh (right)

Figures 11, 12 and 13 show the 3D temperature field, vertical displacement and finally a magnification of the zone near the water basin. Note that the reference (initial) state, for these figures is the excavated state. Symmetry planes are considered on all sides of the model except for the top, which is free of stress. In this preliminary modeling, a Thermal-FSI (Thermal-Fluid Structure Interaction) analysis was not performed in the strict sense of the term. The filling water develops pressure on the walls and floor of the cavity and the temperature (also applied to the walls and floor) affects the boundaries of the basin. This is a strong hypothesis in the sense that the spatio-temporal evolution of the temperature field in water, and therefore on the walls and the floor, were simplified. In other words, $\mathrm{N}$ stationary states in temperature from 10 to $80^{\circ} \mathrm{C}$ within the water are considered.
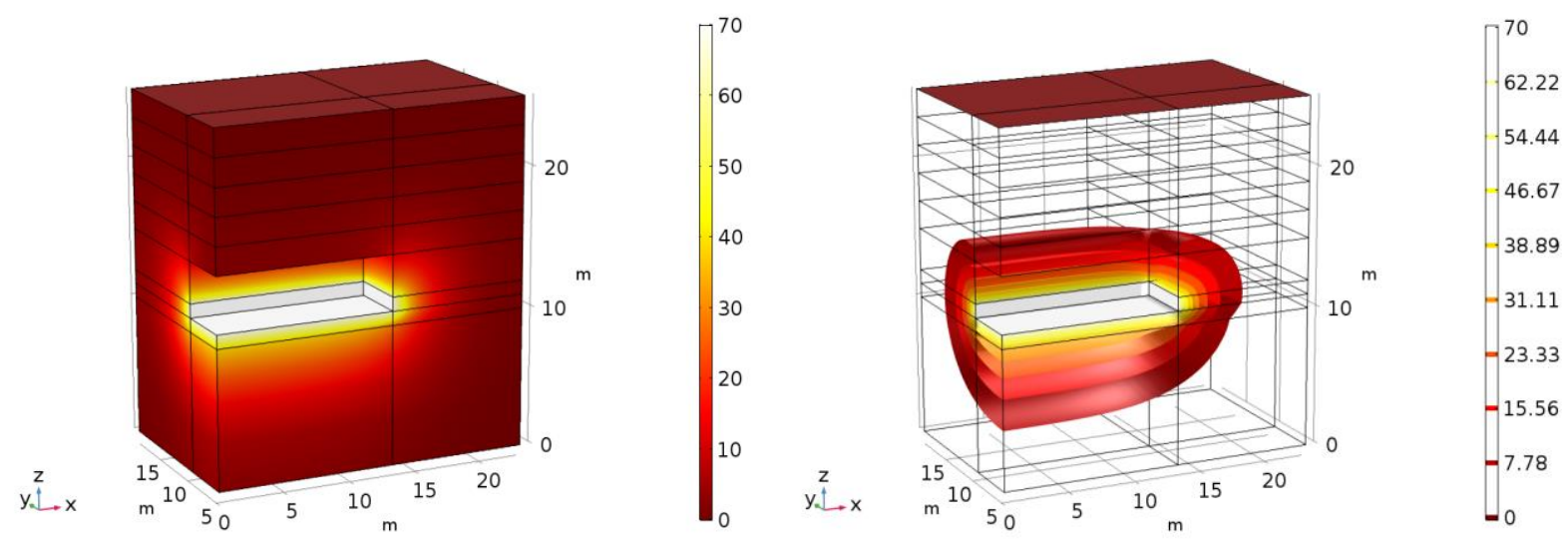
Figure 11. Example 3D field (left) of temperature increment and isovalues (right) after 6 months

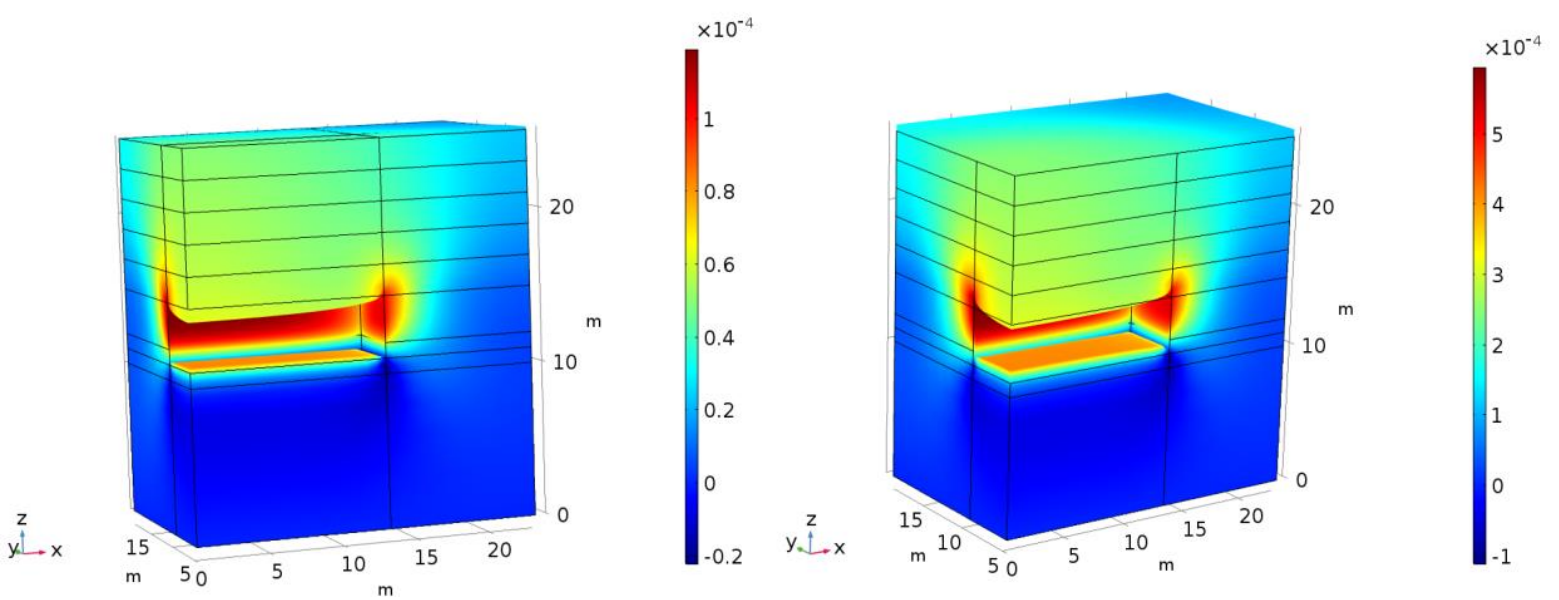

Figure 12. Thermal vertical displacement field (m) $\alpha_{\min }$ (left) and $\alpha_{\max }$ (right) after six months (Magnification of deformation mag $=500$ )

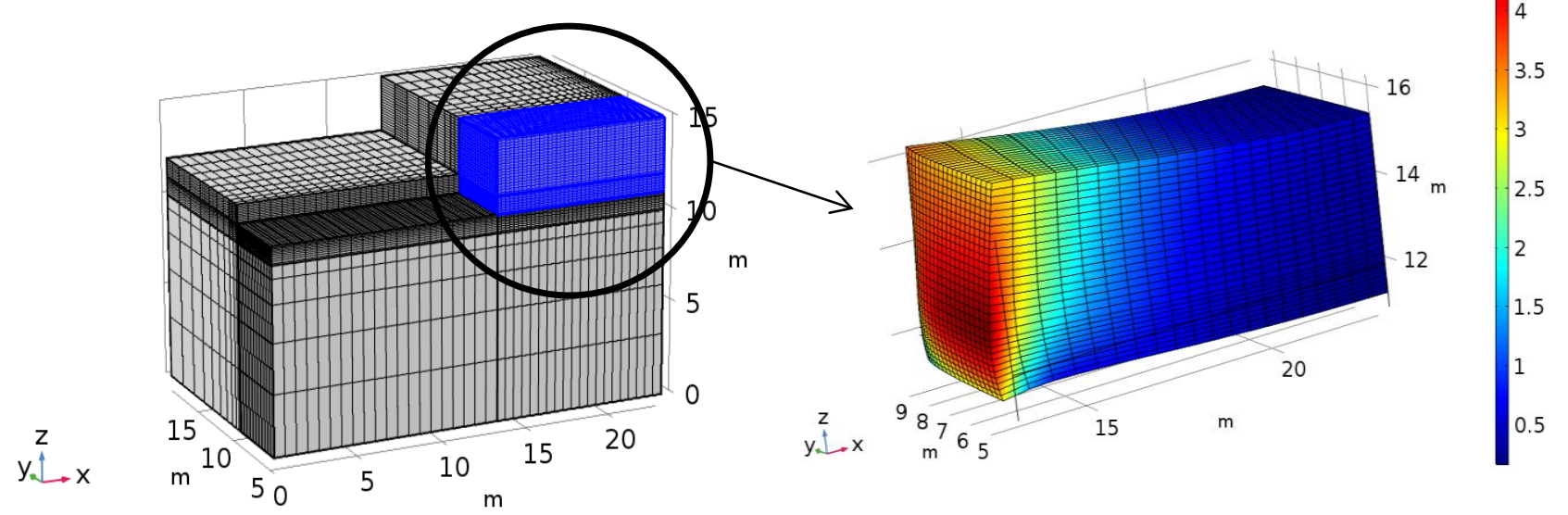

Figure 13. Thermal deformation $(\operatorname{mag}=5000)$ of a wall behind the basin after six months

In terms of initial condition, before cavern creation, the stress state is supposed isotropic and litho-static $\sigma_{z}(z)=\sigma_{x}(z)=\sigma_{y}(z)=\gamma \bar{z} ; \bar{z}$ being the depth of the point in the rock mass.

Once the cavern is created, water pressure and heat are applied on the basin boundaries. Note that the only mechanical load is the gravity load acting on the rock mass. Concerning the effects of a basin full of water and heat on cavern walls we made the following assumptions.

A water pressure $(p(z))$ and temperature $(T(t))$ are applied on all sides of the basin of $1 \mathrm{~m}$ thickness. The analysis time is six months. The time change of this increment is as follows (time $t$ in seconds):

$$
T(t)=\left\{\begin{array}{ccc}
\left(\frac{70}{100 \times 3600}\right) t & \text { if } & t \leq 100 \times 3600 \\
70 & \text { else if } & t>100 \times 3600
\end{array}\right.
$$

In the following, the time change of the vertical (z-displacement) and the horizontal (x-displacement) is analyzed at a $0.50 \mathrm{~m}$ horizontal depth, i.e. the point where the main probes will be placed. The displacement caused by the thermal expansion of the rock would, depending on the expansion coefficient, be about 30 to $250 \mu \mathrm{m}$ in the horizontal plane, and 400 to $560 \mu \mathrm{m}$ in the vertical plane (Figure 14). These values are low, but, repeated each 
year for several decades, could damage the walls, particularly if the increased water content of the rock due to moisture penetration, is taken into account. To check this, several probes will be placed in the wall of the basin: thermal probes, a BDG (Borehole Deformation Gauge) cell to measure the displacement caused by the vertical stress evolution, an extensometer to measure the displacement caused by the horizontal stress evolution, a TDR (Time Domain Reflectometry) probe to measure the water content evolution of the rock. The values thus modeled are indeed in the experimental measurement range of the thermal probes (amplitude of $125^{\circ} \mathrm{C}$ with a precision of $0.1{ }^{\circ} \mathrm{C}$ ), the BDG cell (amplitude of $600 \mu \mathrm{m}$ with a precision of $1 \mu \mathrm{m}$ ), the extensometer (amplitude of $50 \mathrm{~mm}$ with a precision of $20 \mu \mathrm{m}$ ) and the TDR probe (amplitude of $100 \%$ with a precision of $2 \%$ ).
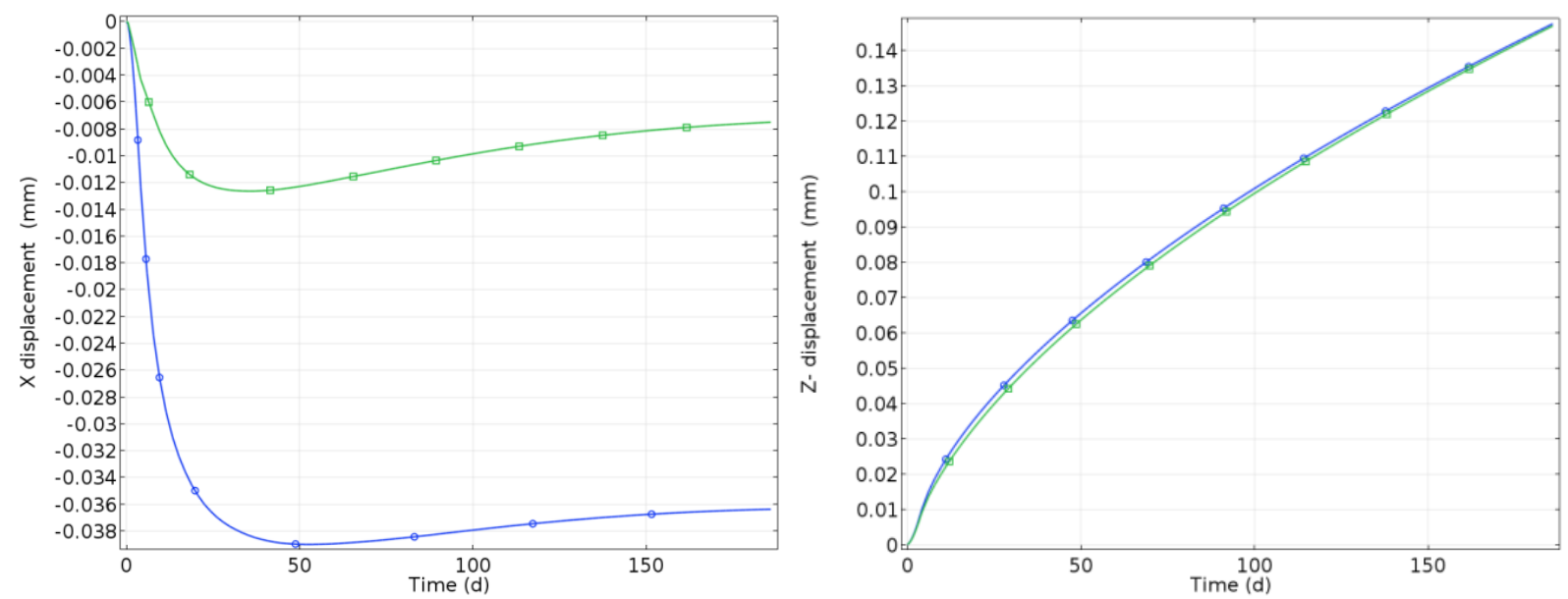

a) for the minimal thermal dilation coefficient
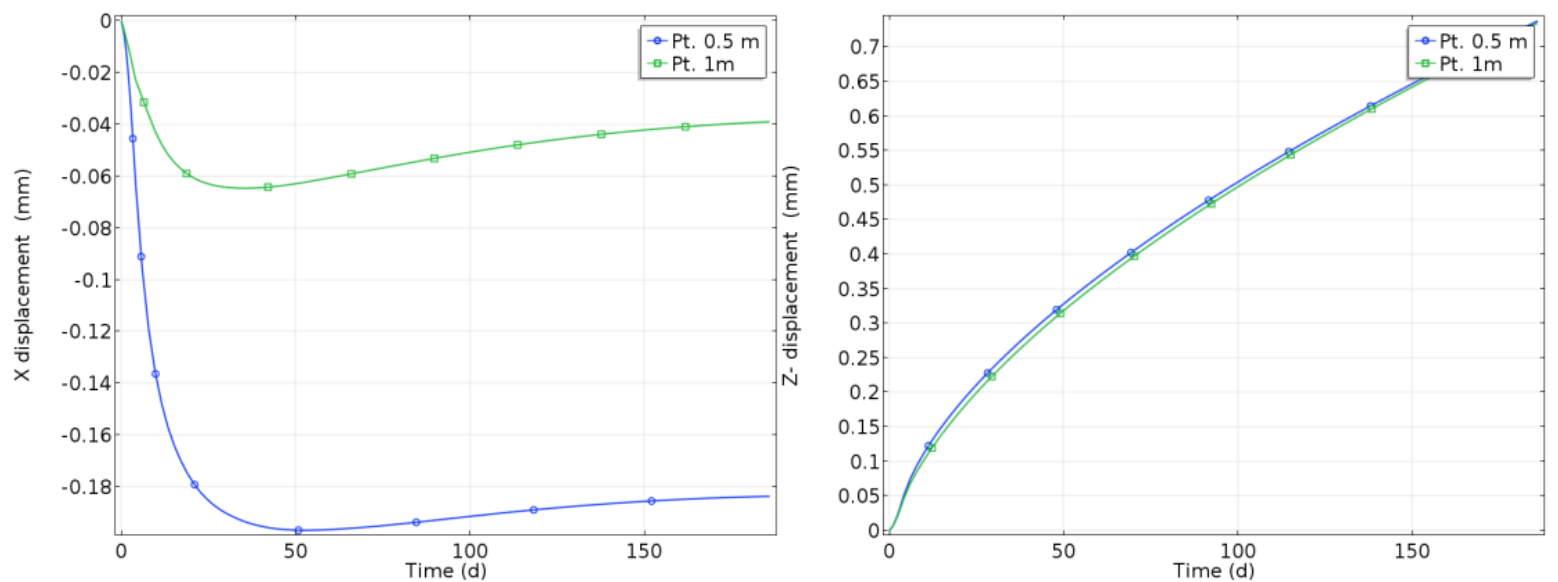

b) for the maximal thermal dilation coefficient

Figure 14. Time evolution of the horizontal (left) and vertical (right) displacement

\subsection{Instrumentation of the site}

The thermo-mechanical impact of this experiment will be monitored using twenty-two probes (Figure 15):

- $\quad$ eighteen thermal probes installed in the air, in the water and in the wall around the basin, up to $1.50 \mathrm{~m}$ deep in the rock wall;

- $\quad$ one Borehole Deformation Gauge (BDG) cell to measure the vertical stress and the induced movement at a depth of 0.50 in the rear wall;

- one dual-anchor extensometer to measure the horizontal stress variation and the induced movement at depths of $0.50 \mathrm{~m}$ and $1 \mathrm{~m}$ in the rear wall;

- $\quad$ one Time Domain Reflectometry (TDR) probe to measure the water content variation of the rock at a depth of $0.25 \mathrm{~m}$ in the rear wall;

- two thermo-hygrometers and one anemometer to measure the flow of hot and moisture-saturated air entering and leaving the device, near the ceiling. 


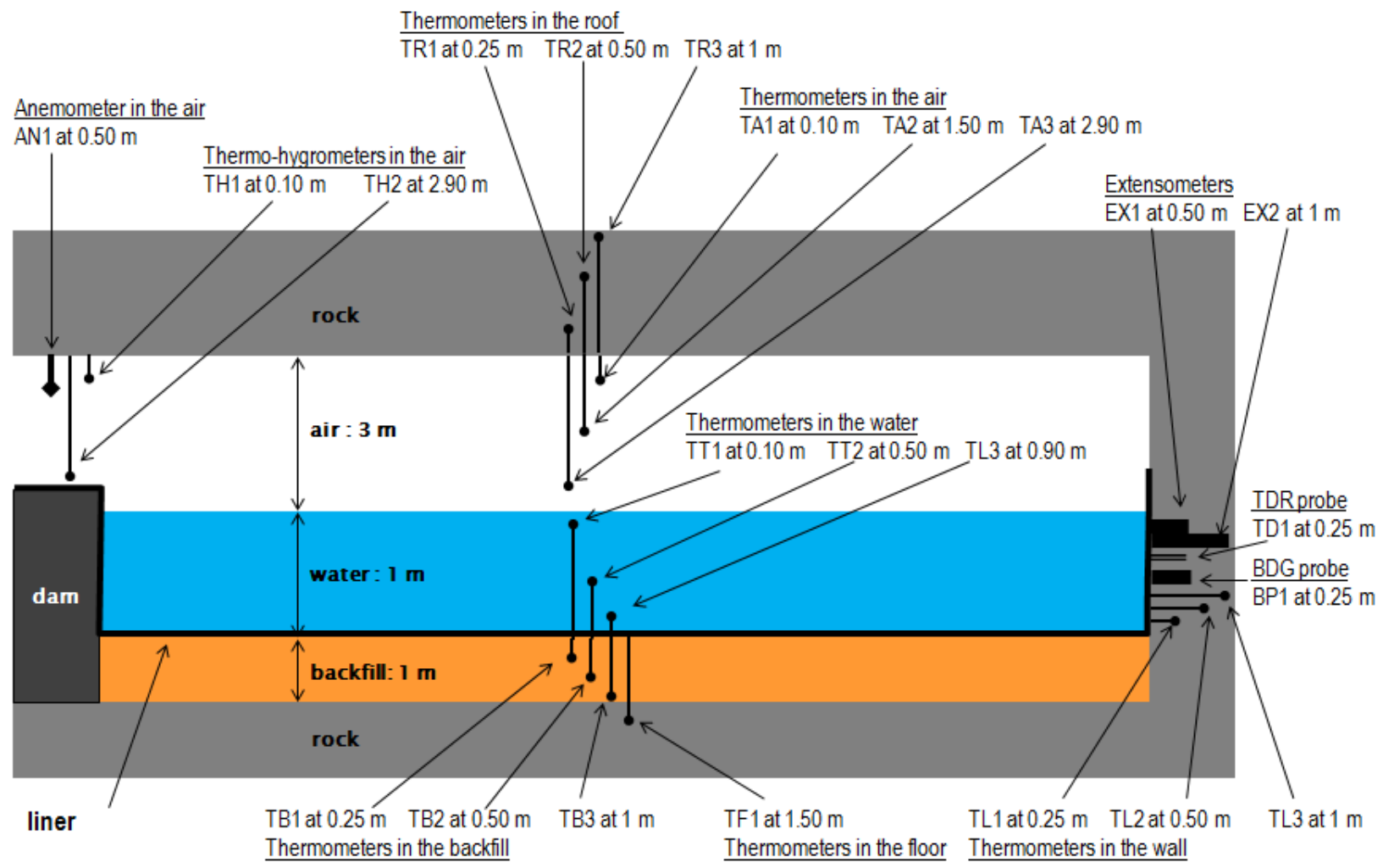

Figure 15. Location of probes in the future basin inside the St-Maximin mine (cross section)

Furthermore, a monthly physicochemical and bacteriological analysis of the water will be conducted in order to estimate the impact of the heating on the chemical equilibria and the initially psychrophilic bacterial populations in the basin. As studied in the context of ATES, for temperatures higher than $40{ }^{\circ} \mathrm{C}$, the bacterial ecosystem may undergo lasting transformations corresponding to the onset of thermophilic conditions (Courtois et al. 2007). This subject, that has not been studied in the context of CTES, is important in case of leaching towards an underlying aquifer.

All the data collected over this annual charge/discharge cycle will be used to model the thermomechanical behavior of the system over several decades. This will involve long-term modeling of the propagation of the thermal plume within the basin and the rock wall, in order to estimate the energy efficiency of the system as well as its geomechanical impact. (cf. Djizanne et al 2012). All experimental and modeling results will be summarized in a risk analysis, which should enable an evaluation of the principal impacts expected for this new type of underground storage.

\section{Conclusion}

The new French law on energy transition will propel the development of underground energy storage sites, especially for thermal energy storage. Several thousands of underground thermal energy storages already exist in the world, but most of them are aquifer storages and less than twenty are cavity storages. These are mainly large caverns, expensive to dig, while there exist hundreds of thousands of mines, already dug and unused. The main differences are that cavern storages are totally full of water and designed with a low diameter-height ratio $(<5)$, while mines are only partially flooded (naturally or artificially) and have high diameter-height ratios $(>10)$. The presence of air and a design that is not optimal in terms of heat loss, can call into question the profitability of this type of storage. This necessitates the building and study of an underground experimental site in an abandoned mine.

The objective of the Demosthene project is to demonstrate the feasibility of this approach in the Picardy region based on the creation and monitoring of an underground experimental thermal storage site. The purpose of this site is to test the possibility of storing the thermal energy needed for winter heating, and to a lesser extent for summer air-conditioning, of a small collective unit (gymnasium, school group, shopping center, office building, etc.). The required volume of water has been was estimated at between 1,900 and 7,600 $\mathrm{m}^{3}$, depending on the temperature of the stored water. Taking into account a minimum water depth of $1 \mathrm{~m}$ and an extraction ratio of 
$75 \%$, the minimum mine surface area necessary to meet this condition is from 2,500 to $10,100 \mathrm{~m}^{2}$. Shallow abandoned mines with a surface area greater than or equal to $1 \mathrm{Ha}$ and naturally flooded have therefore been sought out. Among the 30,000 potential cavities in the Picardy region, between 1,800 and 3,600 correspond to proven and localized old mines. But only forty meet the first criterion, and only one meets the second criterion: it is a chalk mine located in Saint-Martin-le-Noeud (Oise), the deepest galleries of which are flooded.

In order for the experimental site to be reproducible, the focus therefore turned toward dry mines with a sufficient surface area, and the possibility of producing an artificial flooding system therein: excavating basins or sealing galleries. This theoretically represents more than a thousand sites in Picardy, forty of which are already known and localized located. The most interesting of these sites is located in Saint-Gobain (Aisne). It includes several basins of about $1,000 \mathrm{~m}^{3}$, artificially excavated within the Lutetian limestone and able to be filled with water via an aqueduct. Nevertheless, the volume of the basins will require too long a heating time compared to the duration of the experiment, and it is not certain that the water filling will hold during all this time.

Finally, the selected solution was to build a basin in another dry limestone mine located at Saint-Maximin (Oise). This basin was produced by sealing the floor and the walls with a liner, and by building a masonry wall as a dam. The perfect sealing will theoretically allow storage of hot water $\left(80^{\circ} \mathrm{C}\right)$ in a limited volume of $120 \mathrm{~m}^{3}$, which corresponds to an experimental underground thermal energy storage site on a 1/10 scale. The basin and its walls were then equipped with eighteen sensors to measure temperature, humidity and strain.

Thermomechanical and hydromechanical models modeling was carried out on this site in order to optimize the position of the various sensors, and to predict the future deformations induced on the walls by the thermal variations. The propagation of the thermal plume in the water, air and rock will be monitored using the thermometers installed at various depths, and the thermomechanical response of the rock will be monitored using an extensometer, a BDG cell and a TDR probe. Additionally, physicochemical and bacteriological analyses of the water will be performed regularly.

The next step of the project will consist of filling the basin with cold water, producing the zero state of the site, then successively heating it during summer and cooling it during winter. At the end of this experiment the performance of the system will be calculated by hydrothermal modeling for several annual charge/discharge cycles. At the end of the heating/cooling cycle, which will last one year, the collected data will make it possible to calculate the energy efficiency of the heat storage and to model it over several decades. A risk analysis will then be performed to study the impact of such thermal energy storage on the underground environment. The relevance of the presented solution will only be confirmed under these conditions.

\section{References}

Allen RD, Kannberg LD, Raymond JR (1984) Seasonal thermal energy storage. Pacific Northwest Laboratory, Technical Report PNL-5067, 130 p.

Arnould M, Deveughele M, Efforsat J (1983) Utilisation de carrières souterraines de la région parisienne pour stockage intersaisonnier d'énergie solaire pour l'habitat. La Houille Blanche, 3/4, 1985: 283-288.

Axelsson CL, Carlstedt A, Johnson J, Karlqvist L, Lintu Y, Olsson T, Särnblad L (1985) Hydrogeological investigations at the storage cavern for heated water at Avesta. Hydrogeology in the Service of Man, Proc. of the $18^{\text {th }}$ Cong. of the Int. Assoc. of Hydrogeologists, Cambridge, 104-116.

Barron R F, Barron B R (2012) Design for Thermal Stresses. John Wiley \& Sons.

Bourbiaux B (2011) ATES Contribution to the Housing Energy Balance: a Simple Assessment Methodology. Oil \& Gas Science and Technology, Rev. IFP Energies Nouvelles, Vol. 66 (2011), Nr. 1: 21-36.

Brunström C, Larsson M, Holst P, Zinko H, Hillström CG (1985) The Lyckebo rock cavern seasonal storage plant after one year of operation. Sunworld, 9, 3: 93-95.

Chwieduk D (1997) Underground thermal energy storage in Poland. http://intraweb.stockton.edu/eyos/energy studies/content/docs/proceedings/CHWIE.PDF, accessed 24 October 2016.

Courtois N, Marchal JP, Menjoz A, Monnot P, Noël Y, Petit V, Thiéry D, Grisey A, Grasselly D (2007) Application du stockage thermique en aquifère au chauffage et au refroidissement de serres maraîchères en France : étude de préfaisabilité. Rapport BRGM/RP 55481-FR.

Dannemand AJ, Bødker L, Jensen MV (2013) Large Thermal Energy Storage at Marstal District Heating. Proceedings of the 18th International Conference on Soil Mechanics and Geotechnical Engineering, Paris 2013: 3351-3354. 
Djizanne H, Bérest P, Brouard B (2012) Tensile effective stresses in hydrocarbon storage caverns. Solution Mining Res. Inst., Fall 2012 Technical Conf. Bremen, Germany,1-2 October 2012.

DGALN (2011) Réglementation thermique 2012: un saut énergétique pour les bâtiments neufs. Direction Générale de l'Aménagement, du Logement et de la Nature, avril 2011.

Desmedt J, Hoes H, Van Bael J (2006) Status of underground thermal energy storage in Belgium. https://intraweb.stockton.edu/eyos/energy studies/content/docs/FINAL_PAPERS/3A-3.pdf, accessed 24 October 2016.

Fjaer E, Holt R M, Horsrud P, Raaen A M, Risnes R (1992) Petroleum related rock mechanics. Elsevier

Fogelholm CJ, Gebremedhin A, Kim S, Pedersen L, Savola T, Stang J, Tveit TM, Zinko H (2008) Improved cogeneration and heat utilization in DH networks. The $11^{\text {th }}$ Int. Symp. on District Heating and Cooling, August 31 to September 2, 2008, Reykjavik, Iceland: 1-2.

Gedung H, Margen P (1988) Converted oil cavern used for thermal energy storage, in STES Newsletter, 10, 2 , June 1988

Gurtin M E, Fried E, Anand L (2009) The Mechanics and Thermodynamics of Continua. Cambridge University Press.

Hellström G (2012) UTES Experiences from Sweden. Underground Thermal Energy Storage Seminar. 31 May 2012, London.

Holzapfel G A (2000) Nonlinear Solid Mechanics, Wiley.

IEA (1983) Central solar heating plants with seasonal storage. Int. Energy Agency, Solar heating and cooling program, task VII, June 1983, 212 p.

INERIS (2016) Le stockage souterrain dans le contexte de la transition énergétique : maîtrise des risques et impacts. Dossier INERIS Références, septembre 2016, www.ineris.fr

Jaeger J C, Cook N G W, Zimmerman R W (2007) Fundamentals of Rock Mechanics. Fourth Edition. Blackwell.

Kabuth A, Dahmke A, Beyer C, Bilke L, Dethlefsen F, Dietrich P, Duttmann R, Ebert M, Feeser V, Görke UJ, Köber R, Rabbel W, Schanz T, Schäfer T, Würdemann H, Bauer S (2016) Energy storage in the geological subsurface: dimensioning, risk analysis and spatial planning: the ANGUS+ project. Environ Earth Sci (2017) 76:23, DOI 10.1007/s12665-016-6319-5

Martna J (1983) The Avesta research plant for hot water storage - State of the project. Swedish Council for Building Research, Stockholm, Suède, 1983, 16: 367-372.

Midttomme K, Banks D, Kalskin Ramstad R, Saether OM, Skarphagen H (2008). Ground-source heat pumps and underground thermal energy storage - Energy for the future. In Slagstad, T. (ed.) Geological Survey of Norway special publication, 11: 93-98.

Montjoie A (1981) Stockage de chaleur dans les excavations à ciel ouvert ou souterraines. Revue Française de Géotechnique, 14BIS: 241-247.

Nielsen K (2003) Thermal Energy Storage - A state-of-the-Art. A report within the research program Smart Energy-Efficient Buildings at NTNU and SINTEF 2002-2006.

Paksoy HO, Andersson O, Abaci S, Evliya H, Turgut B (2000) Heating and cooling of a hospital using solar energy coupled with seasonal thermal energy storage in aquifer. Renewable energy 19: 117-122.

Sanner B, Bartels J (2009) Thermal energy storage in aquifers - three decades of experience gained, and what are future prospects? EGEC, IFP. Deep saline aquifers for geological storage of $\mathrm{CO}_{2}$ and energy, Rueil-Malmaison, France, 17 April 2009.

Seibt P, Kabus F (2006) Aquifer thermal energy storage-Projects implemented in Germany. Proc. ECOSTOCK 2006, Stockton, NJ, USA.

Sipilä K (1990) Converting an old rock cavern into heat storage in Finland. Fernwärme international. District Heating Fernwärme Chauffage Urbain, 19, 5: 382 - 836.

Somerton W H (1992) Thermal properties and temperature-related behavior of rock/fluid systems. Elsevier.

Tritsch JJ (2007) Mise en sécurité des cavités souterraines d'origine anthropique : Surveillance - traitement. Guide technique. Rapport INERIS-DRS-07-86042-02484A, 15/02/2007. 
Verhoeven R, Willems E, Harcouët-Menou V, De Boever E, Hiddes L, Op 't Veld P, Demollin E (2014) Minewater 2.0 project in Heerlen the Netherlands: transformation of a geothermal mine water pilot project into a full scale hybrid sustainable energy infrastructure for heating and cooling. Energy Procedia 46 (2014) 58-67, https://doi.org/10.1016/j.egypro.2014.01.158.

Walton M, McSwiggen P (1982) Heat Storage in deep mines at Ely, Minesota. In STES Newsletter, September 1982, vol.IV, $\mathrm{n}^{\circ} 4$.

Wille A, Lottner V (2006) R\&D program on thermal energy storage in Germany. Proc. ECOSTOCK 2006, Stockton, NJ, USA. 